\title{
Effect of Biofertilizers on Growth and Yield of Tomato (Lycopersicon esculentum Mill)
}

\author{
Shashi Kamal, Mohit Kumar*, Rajkumar and Manoj Raghav \\ Department of Vegetable Science, College of Agriculture, G.B.P.U.A. \& T., \\ Pantnagar-263145, U.S. Nagar, Uttarakhand, India \\ *Corresponding author
}

\begin{tabular}{|l|}
\hline Ke y w or d s \\
Tomato, \\
Biofertilizers, \\
Growth and Yield \\
\hline Article Info \\
\hline $\begin{array}{l}\text { Accepted: } \\
\text { 24 January } 2018 \\
\text { Available Online: } \\
\text { 10 February } 2018\end{array}$ \\
\hline
\end{tabular}

\section{Introduction}

Tomato (Lycopersicon esculentum Mill) is one of the most popular and widely grown vegetable in India. It covers $7.9 \%$ of total area grown under vegetable crops and $9 \%$ of total vegetable production. The average yield of tomato in India is not according to the crop potential. Various factors are responsible for its low yield, inadequate use of fertilizers is one of them. The crop particularly hybrids have higher requirements of nutrients. Low use of fertilizers and imbalance in NPK application ratio is partially responsible for the low yield. Moreover, complete dependence on chemical fertilizers is not sufficient to sustain the higher yields. Also, due to high cost of inorganic fertilizers, sometimes the margin of profit remains poor. The use of biofertilizers along with inorganic fertilizers may be the right answer to above mention problems. Biofertilizers, which are eco-friendly and more economic, can play an important role in reducing the dependence on chemical fertilizers. Biofertilizers fix appreciable amount of atmospheric nitrogen in soil, enhance plant growth by production of organic acid and growth hormones and make available 
the complex phosphorus to the plant, which may cause an appreciable reduction in consumption of inorganic fertilizers. Keeping these in view, response of inoculation of biofertilizers on growth and yield of tomato were carried out under field condition.

\section{Materials and Methods}

The field experiment was carried out with nine treatments, which includes two levels of nitrogen and phosphorus $(75 \%$ and $100 \%$ of recommended dose i.e., 120:100:100 kg NPK per hectare) with $\mathrm{N}$-fixing bacteria (Azospirillum and Azotobacter) and phosphorus solublizing bacteria (PSB and VAM) along with control (only chemical fertilizers). The experiment was laid out in randomized block design with three replications. Thirty eight days old seedlings were transplanted (after biofertilizers treatment) in respective experimental plots of $3 \mathrm{X} 3 \mathrm{~m}^{2}$ size at $60 \mathrm{X} 50 \mathrm{~cm}$ spacing in last week of February, 2006. Full dose of phosphorus and potassium in the form of single super phosphate and murate of potash, respectively, and half dose of nitrogen in the form of urea per treatment were applied before transplanting and rest half dose of nitrogen applied as top dressing after a month of transplanting.

All cultural operation was done as per the need of crop in all the plots. Plant height was measured at 30, 45, 60, 75, 90 days after transplanting and at final harvest with meter scale. Days to first harvest was recorded as days taken from transplanting to the stage when total yield from one plot weighed at least $500 \mathrm{~g}$ and the stage when remaining yield from one plot weighed at least $500 \mathrm{~g}$ was record as days to final harvest. Plants were cut at the time of final harvest from the ground level and weighed to get plant fresh weight. These cut plants kept for sun drying for 3-4 days and then in oven at $55^{\circ} \mathrm{C}$ for $6-8$ days after that plant dry weight was recorded. Number of primary branches, stem diameter (cm) and number of fruits per plant were observed at final harvest. Leaf Area Index was calculated with help of leaf area meter. Total fruit yield $(\mathrm{q} / \mathrm{ha})$ was computed on the basis of per plot yield.

\section{Results and Discussion}

It can be observed from table 1 and 2 that significant difference was seen for plant fresh weight, plant dry weight, stem diameter, fruits per plant and yield whereas, plant height, days to first harvest, days to final harvest and number of primary branches was not found to differ significantly. There was continuous increase in the plant height right from the transplanting to the day of harvesting but there was no significant difference among the treatments at all the stages. At 30, 45 and 60 days after transplanting (DAT) treatment $\mathrm{T}_{7}$ showed maximum plant height $(49.33,71.60$ and $85.00 \mathrm{~cm}$, respectively) but at $75 \mathrm{DAT}$ treatment $\mathrm{T}_{3}$ showed maximum plant height $(96.93 \mathrm{~cm})$. However, at 90 DAT and at final harvest treatment $T_{2}$ gave maximum plant height $(115.73$ and $121.07 \mathrm{~cm}$, respectively). Azospirillum inoculated tomato plants showed increase plant height than uninoculated ones (Terry et al., 2000). It was observed that biofertilizers marginally increase the Leaf Area Index of tomato plant over control in all treatments except treatment $\mathrm{T}_{6}(\mathrm{PSB}+75 \% \mathrm{P}$ + full $\mathrm{N}$ and $\mathrm{K}$ of recommended dose). The highest Leaf Area Index was recorded in treatment $\mathrm{T}_{5}$ (Azotobacter + recommended dose of NPK) and treatment $\mathrm{T}_{8}(\mathrm{VAM}+75 \%$ $\mathrm{P}+$ full $\mathrm{N}$ and $\mathrm{K}$ of recommended dose). The application of Azotobacter increases the number of leaves in tomato (Mamatha and Bagyaraj, 2003). Application of Azotobacter and Azospirillum with $100 \% \mathrm{~N}$ reduced the days taken to first harvest and increased the total crop duration in comparison to when these applied with $75 \% \mathrm{~N}$. 
Table.1 Effect of biofertilizers on plant height $(\mathrm{cm})$ at various stages of crop growth

\begin{tabular}{|c|c|c|c|c|c|c|}
\hline \multirow[t]{2}{*}{ Treatments } & \multicolumn{6}{|c|}{ Plant height (cm) } \\
\hline & 30 DAT & 45 DAT & 60 DAT & 75 DAT & 90 DAT & At final harvest \\
\hline T1-Recommended N,P and K through chemical fertilizers (Control) & 48.7 & 68.2 & 81.9 & 93.7 & 112.2 & 114.7 \\
\hline T2-Azospirillum $+75 \% \mathrm{~N}$ and recommended $\mathrm{P}$ and $\mathrm{K}$ through chemical fertilizers & 48.2 & 68.9 & 83.8 & 93.8 & 115.7 & 121.0 \\
\hline T3- Azospirillum + recommended N,P and K through chemical fertilizers & 47.4 & 68.5 & 86.7 & 96.9 & 115.0 & 120.2 \\
\hline T4-Azotobacter $+75 \% \mathrm{~N}$ and recommended $\mathrm{P}$ and $\mathrm{K}$ through chemical fertilizers & 45.0 & 64.0 & 80.8 & 92.8 & 107.9 & 114.3 \\
\hline T5 Azotobacter + recommended N,P and K through chemical fertilizers & 47.1 & 69.5 & 83.4 & 94.4 & 113.6 & 119.3 \\
\hline T6- PSB $+75 \% \mathrm{P}$ and recommended $\mathrm{N}$ and $\mathrm{K}$ through chemical fertilizers & 42.5 & 64.4 & 82.8 & 93.3 & 105.6 & 115.2 \\
\hline T7-PSB + recommended N,P and K through chemical fertilizers & 49.3 & 71.6 & 85.0 & 94.5 & 110.0 & 116.9 \\
\hline T8- VAM $+75 \% \mathrm{P}$ and recommended $\mathrm{N}$ and $\mathrm{K}$ through chemical fertilizers & 48.0 & 70.6 & 84.4 & 94.0 & 110.3 & 114.3 \\
\hline T9- VAM + recommended N,P and K through chemical fertilizers & 45.4 & 69.5 & 82.5 & 92.5 & 107.0 & 112.0 \\
\hline $\mathrm{CD}$ at $5 \%$ & NS & NS & NS & NS & NS & NS \\
\hline
\end{tabular}

Table.2 Effect of biofertilizers on growth and yield of tomato

\begin{tabular}{|c|c|c|c|c|c|c|c|c|c|}
\hline Treatments & $\begin{array}{l}\text { Leaf Area } \\
\text { Index }\end{array}$ & $\begin{array}{l}\text { Days to } \\
\text { first } \\
\text { harvest }\end{array}$ & $\begin{array}{l}\text { Total } \\
\text { crop } \\
\text { duration }\end{array}$ & $\begin{array}{l}\text { Fresh } \\
\text { weight/plant } \\
\text { (g) }\end{array}$ & $\begin{array}{l}\text { Dry } \\
\text { weight/plant } \\
\text { (g) }\end{array}$ & $\begin{array}{l}\text { No. of primary } \\
\text { branches/plant }\end{array}$ & $\begin{array}{l}\text { Stem } \\
\text { diameter } \\
(\mathbf{m m})\end{array}$ & $\begin{array}{l}\text { Number of } \\
\text { fruits/plant }\end{array}$ & $\begin{array}{l}\text { Yield } \\
\text { (q/ha) }\end{array}$ \\
\hline $\begin{array}{l}\text { T1-Recommended N,P and K through } \\
\text { chemical fertilizers (Control) }\end{array}$ & 2.76 & 66.67 & 105.66 & 495.33 & 96.67 & 10.77 & 13.22 & 44.86 & 643.32 \\
\hline $\begin{array}{l}\text { T2-Azospirillum }+75 \% \mathrm{~N} \text { andrecommended } \\
\mathrm{P} \text { and } \mathrm{K} \text { through chemical fertilizers }\end{array}$ & 2.82 & 69.67 & 112.33 & 544.67 & 123.00 & 11.88 & 12.67 & 44.47 & 669.99 \\
\hline $\begin{array}{l}\text { T3- Azospirillum + recommended N,P and K } \\
\text { through chemical fertilizers }\end{array}$ & 3.03 & 68.00 & 115.00 & 478.67 & 106.00 & 10.32 & 14.28 & 46.95 & 690.00 \\
\hline $\begin{array}{l}\text { T4-Azotobacter }+75 \% \mathrm{~N} \text { and recommended } \\
\mathrm{P} \text { and } \mathrm{K} \text { through chemical fertilizers }\end{array}$ & 2.87 & 68.00 & 107.00 & 409.00 & 92.00 & 10.22 & 14.14 & 47.15 & 660.00 \\
\hline $\begin{array}{l}\text { T5 Azotobacter + recommended N,P and K } \\
\text { through chemical fertilizers }\end{array}$ & 3.41 & 66.33 & 112.33 & 515.00 & 106.33 & 11.99 & 14.91 & 48.23 & 693.32 \\
\hline $\begin{array}{l}\text { T6- PSB }+75 \% \mathrm{P} \text { and recommended } \mathrm{N} \text { and } \\
\mathrm{K} \text { through chemical fertilizers }\end{array}$ & 2.75 & 67.33 & 107.00 & 442.00 & 86.33 & 10.99 & 14.04 & 41.99 & 573.48 \\
\hline $\begin{array}{l}\text { T7-PSB + recommended N,P and K through } \\
\text { chemical fertilizers }\end{array}$ & 3.05 & 67.33 & 105.00 & 639.33 & 129.00 & 11.33 & 13.66 & 44.82 & 640.00 \\
\hline $\begin{array}{l}\text { T8- VAM }+75 \% \mathrm{P} \text { and recommended } \mathrm{N} \text { and } \\
\mathrm{K} \text { through chemical fertilizers }\end{array}$ & 3.26 & 64.33 & 103.00 & 505.00 & 117.33 & 10.99 & 14.13 & 41.15 & 620.00 \\
\hline $\begin{array}{l}\text { T9- VAM + recommended N,P and K } \\
\text { through chemical fertilizers }\end{array}$ & 3.27 & 67.00 & 100.33 & 381.67 & 84.33 & 10.55 & 15.89 & 39.74 & 556.60 \\
\hline CD at $5 \%$ & NS & NS & NS & 82.57 & 19.83 & NS & 1.31 & 1.81 & 25.84 \\
\hline
\end{tabular}


The least number of first harvest days was found in treatment $\mathrm{T}_{8}(\mathrm{VAM}+75 \% \mathrm{P}+$ full $\mathrm{N}$ and $\mathrm{K}$ of recommended dose).

Treatment $\mathrm{T}_{7}(\mathrm{PSB}+\mathrm{RDF})$ was found superior for per plant fresh weight $(639.33 \mathrm{~g})$ and per plant dry weight $(129 \mathrm{~g})$. However, treatment $\mathrm{T}_{9}$ (VAM + RDF) exhibited lowest fresh weight $(381.67 \mathrm{~g})$ per plant and dry weight $(84.33 \mathrm{~g})$ per plant. The application of biofertilizers with chemical fertilizers increased the fresh and dry weight of tomato shoot (Singh et al., 2004). Highest number of primary branches (12.00) was observed with treatment $T_{5}$. However, treatment $\mathrm{T}_{4}$ recorded least number of primary branches (10.22) per plant. Here, Azotobacter and PSB was found to increase number of primary branches when applied with $100 \%$ NPK dose while such an effect was not observed in Azospirillum and VAM. Similar results were also obtained by other scientist (Gajbhiye et al., 2003). Stem diameter showed wide range i.e., from 12.77 to $15.89 \mathrm{~mm}$. As compared to control $(13.22 \mathrm{~mm})$, treatment $\mathrm{T}_{9}$ recorded highest stem diameter $(15.89 \mathrm{~mm}$ i.e., $15.65 \%$ increase) followed by treatment $\mathrm{T}_{5}$ (14.91 mm i.e., $12.78 \%$ increase). Interestingly, all biofertilizers except PSB was found to increase stem diameter when applied with full recommended dose.

Highest number of fruits per plant (48.23) was recorded with treatment $T_{5}$. Application of PSB and VAM with RDF increased the fruits per plant but there was no effect when applied with $75 \%$ phosphorus. While application of Azotobacter and Azospirillum was showed positive effect on fruits per plant. Highest yield $(693.32 \mathrm{q} / \mathrm{ha})$ was recorded with treatment $\mathrm{T}_{5}$ (Azotobacter $+\mathrm{RDF}$ ) followed by treatment $\mathrm{T}_{3}$ (690.00 q/ha) and $\mathrm{T}_{2}$ (669.99 q/ha). Treatment $\mathrm{T}_{9}(\mathrm{VAM}+\mathrm{RDF})$ gave lowest yield (556.60 $\mathrm{q} / \mathrm{ha}$ ). It was reported that when tomato seedlings inoculated with Azotobacter and Azospirillum improved crop growth and yield as compared to uninoculated ones (Sengupta et al., 2002). Increase in the growth attributes and yield may be due to slow but steady effect of biofertilizers, which fix some nutrients and make it available to the plant.

On the basis of the experimental findings, application of Azotobacter + recommended dose of NPK and Azospirillum + recommended dose of NPK (160:90:90 kg/ha) through chemical fertilizers gave better plant growth and fruit yield.

\section{References}

Gajbhiye, R.P., Sharma, R.R. and Tewari, R.N. 2003. Effects of biofertilizers on the growth and yield parameters of tomato. Indian J. of Hort., 60 (4): 368-371.

Mamatha, G. and Bagyaraj, D. J. 2003. Effect of different methods of VAM inoculum application on growth and nutrient uptake of tomato seedlings grown in raised nursery beds. Advances in Agricultural Biotech. 2003: 113-119.

Sengupta, S.K., Dwivedi, Y.C. and Kushwah, S.S. 2002. Response of tomato (Lycopersicon esculentum Mill.) to bio-inoculants at different levels of nitrogen. Veg. Sci., 29 (2): 186-188.

Singh, T.R., Singh, S., singh, S.K., Singh, M.P. and Srivastava, B.K. 2004. Effect of integrated nutrient management on crop nutrient uptake and yield under okra-peatomato cropping system in a Mollisol. Indian J. of Hort., 61 (4): 312-314.

Terry, E., Pino, M-de-los-A., and Medina, N. 2000. Application times of an Azospirillum byproduct in tomato growth, development and yield. Cultivos Tropicales, 21 (4): 5-8.

\section{How to cite this article:}

Shashi Kamal, Mohit Kumar, Rajkumar and Manoj Raghav. 2018. Effect of Biofertilizers on Growth and Yield of Tomato (Lycopersicon esculentum Mill). Int.J.Curr.Microbiol.App.Sci. 7(02): 2542-2545. doi: https://doi.org/10.20546/ijcmas.2018.702.309 